\title{
PI7-I0. A new AuxoGTU-HIV B DNA vaccine induce very long lasting HIV specific $T$ cells response which is efficiently boosted with HIV LAI lipopeptides
}

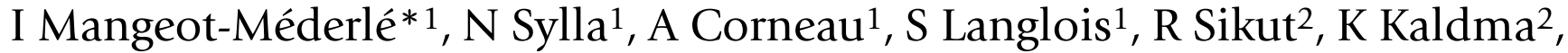 \\ I Stanescu ${ }^{2}, \mathrm{M}$ Ustav $^{2}$, Y Lévy ${ }^{3}$, N Derreudre-Bosquet ${ }^{1}$, R Le-Grand ${ }^{1}$, \\ F Martinon ${ }^{1}$ and A Vaccine Program ${ }^{4}$
}

Address: ${ }^{1} \mathrm{IMETI} / \mathrm{Imm}$ uno-virology Division, Commissariat à l'énergie atomique, Fontenay aux Roses, France, ${ }^{2}$ FitBiotech, Tampere, Finland, ${ }^{3}$ Henri Mondor Hospital, Clinical Immunology Division, Créteil, France and ${ }^{4}$ ANRS, Paris, France

* Corresponding author

from AIDS Vaccine 2009

Paris, France. 19-22 October 2009

Published: 22 October 2009

Retrovirology 2009, 6(Suppl 3):P292 doi:10.1 186/1742-4690-6-S3-P292

This abstract is available from: http://www.retrovirology.com/content/6/S3/P292

(c) 2009 Mangeot-Méderlé et al; licensee BioMed Central Ltd.

\section{Background}

Prime-boost strategies are thought to increase the durability and the breadth of vaccine induced responses and we have recently shown that the use of a novel DNA vector, auxo-GTU ${ }^{\circledR}$-MultiHIV-B is able to induce high level and long-lasting HIV specific T-cell responses in macaques. In addition, lipopeptides based on a palmitoyl group can efficiently process and present peptides by dendritic cells to $\mathrm{CD} 8+\mathrm{T}$ cells and have been shown immunogenic in animal models and in human.

The objective of this study was to boost auxo-GTU ${ }^{\circledR}$-MultiHIV-B induced T-cell responses with lipopeptides based HIV-1 vaccine after 2 years of last DNA vaccine injection.

\section{Methods}

Cynomolgus macaques were primed with three (weeks 0 , 4 and 12) intradermal injections (ID) with or without electroporation of auxo-GTU ${ }^{\circledR}$-MultiHIV-B DNA vector. Animals received two distant booster injections of a multi-component vaccine composed of $5 \mathrm{HIV}$ LAI lipopeptides containing peptides derived from HIV-1 Gag, Nef and Pol proteins.

\section{Results}

ID with auxo-GTU-MultiHIV-B DNA followed by EP induced IFN $\gamma$ producing cells lasting for 3 years after the last plasmid injection. Production of IFN $\gamma$ by PBMC was observed in response to all injected lipopeptides. After a single injection of Lipo5, we observed an increase in IFN $\gamma$ production of PBMC against Gag17-35 and Gag253-284 lipopeptides in auxo-GTU-MultiHIV-B primed animals. A second Lipo5 injection increased these responses and induced IFN $\gamma$ responses against Nef66-97 and Nef116145 lipopeptides. Furthermore, we observed that two injections of Lipo5 were sufficient to induce IFN $\gamma$ response against the 5 studied lipopeptides in one naïve macaque indicating that Lipo5 can prime an HIV specific response in macaques.

\section{Conclusion}

HIV-1 based lipopeptides are able to induce poly-epitopic $\mathrm{T}$-cell responses in macaques and efficiently boost responses primed two years ago by DNA vaccination. 